\title{
Pengaruh Rasio Keuangan, Tata Kelola Perusahaan Terhadap Kesulitan Keuangan Pada Perusahaan Pertambangan
}

\author{
Marfianto dan Nuryasman MN. \\ Program Studi Manajemen Fakultas Ekonomi, Universitas Tarumanagara, Jakarta \\ Email: marfianto29@gmail.com
}

\begin{abstract}
Abstrak: Penelitian ini bertujuan untuk menguji apakah (1) kepemilikan manajerial berpengaruh terhadap kesulitan keuangan (2) kepemilikan institusional berpengaruh terhadap kesulitan keuangan (3) likuiditas berpengaruh terhadap kesulitan keuangan (4) leverage berpengaruh terhadap kesulitan keuangan. Data dikumpulkan dengan metode sensus, sehingga terkumpul 39 perusahaan pertambangan. Teknik analisis data menggunakan teknik analisis regresi logistik. Data diolah dengan menggunakan Eviews 9.0. Hasil penelitian ini menunjukkan bahwa kepemilikan manajerial, kepemilikan institusional dan leverage mempunyai pengaruh positif terhadap kesulitan keuangan. Sedangkan, likuiditas mempunyai pengaruh negatif terhadap kesulitan keuangan.
\end{abstract}

Kata kunci : Kepemilikan Manajerial, Kepemilikan Institusional, Likuiditas, Leverage, Kesulitan keuangan

Abstract: The purpose of this research is to examine whether (1) managerial ownership effect to financial distress (2) institusional ownership effect to financial distress (3) liquidity effect to financial distress (4) leverage effect to financial distress. Data collection was done by census method., so that 39 mining companies were collected. Data analysis techniques using logistic regression analysis techniques. Data is processed using EViews 9.0. The results of this study indicate that managerial ownership, institusional ownership, and leverage is a positive effect to financial distress. while, liquidity is a negative effect to financial distress.

Keywords : Managerial Ownership, Institusional Ownership, Liquidity, Leverage, financial distress

\section{LATAR BELAKANG}

Permasalahan ekonomi yang terjadi pada tahun 2014 terutama di sektor pertambangan, akibat kebijakan pemerintah secara resmi melarang kegiatan ekspor mineral mentah sebagai implementasi UU Nomor 1 tahun 2014 tentang minerba sehingga menimbulkan kendala yang dihadapi perusahaan. Kendala ini menyebabkan perusahaan akan mengalami kekurangan pemasukkan dari luar negeri, kegagalan, ketidakmampuan serta keterpurukan yang dialami perusahaan dapat diindikasikan adanya kesulitan keuangan atau yang sering disebut financial distress. 
Industri pertambangan adalah salah satu penopang pembangunan yang ada dalam suatu negara, karena berperan penting dalam penyedia sumber daya energi yang sangat diperlukan dan membutuhkan modal yang besar dalam melakukan kegiatan operasional pertambangan.

Tabel 1. Daftar Laba Usaha beberapa Perusahaan Sektor Pertambangan (dinyatakan dalam juta rupiah)

\begin{tabular}{|l|l|l|l|l|l|l|}
\hline \multicolumn{1}{|c|}{$\begin{array}{c}\text { Sub } \\
\text { Sector }\end{array}$} & \multicolumn{1}{c|}{$\begin{array}{c}\text { Nama } \\
\text { Perusahaan }\end{array}$} & \multicolumn{1}{c|}{$\mathbf{2 0 1 4}$} & \multicolumn{1}{c|}{$\mathbf{2 0 1 5}$} & \multicolumn{1}{|c|}{$\mathbf{2 0 1 6}$} & \multicolumn{1}{|c|}{$\mathbf{2 0 1 7}$} & \multicolumn{1}{c|}{$\mathbf{2 0 1 8}$} \\
\hline Batubara & ARII & $-306,149$ & $-357,568$ & $-342,376$ & $-226,482$ & $-96,113$ \\
& ATPK & 52,940 & $-161,556$ & $-288,022$ & $-309,130$ & $-83,410$ \\
& PKPK & $-28,432$ & $-61,713$ & $-13,670$ & $-10,440$ & 25 \\
\hline Logam \& & CKRA & $-281,665$ & $-54,668$ & $-54,180$ & $-260,063$ & $-4,303$ \\
Mineral & DKFT & $-46,208$ & $-32,645$ & $-87,161$ & $-44,594$ & $-88,846$ \\
& CITA & $-384,699$ & $-341,206$ & $-265,247$ & 47,493 & 556,904 \\
\hline Minyak \& & APEX & $-197,976$ & 272,420 & $-263,034$ & $-1,338,980$ & $-356,903$ \\
Gas Bumi & BIPI & 95,069 & $-555,064$ & $-2,318,669$ & 516,828 & 160,208 \\
\hline Batu- & MITI & 7,609 & $-179,561$ & $-23,362$ & $-23,354$ & 20,206 \\
Batuan & CTTH & 1,014 & 1,950 & 20,881 & 4,717 & 3,214 \\
& & & & & & \\
\hline
\end{tabular}

Sumber : Data diolah dari IDX tahun 2014-2018

Berdasarkan tabel 1 menggambarkan bahwa dari beberapa sektor pertambangan yang terdaftar di Bursa Efek Indonesia (BEI), rata-rata perusahaan mengalami pergerakan penurunan laba bersih. Apabila permasalahan seperti diatas terus-menerus berlangsung kemungkinan besar perusahaan akan mengalami kondisi financial distress (kesulitan keuangan). Kondisi financial distress tidak hanya merugikan perusahaan saja, akan tetapi pihak stakeholder dan shareholder juga akan terkena dampaknya.

Tujuan perusahaan yang harus dicapai yaitu dengan melakukan pengelolaan perusahaan secara optimal. pengelolaan ini berkaitan dengan pemberian kepercayaan principal kepada agen (manajemen) dalam mengelola perusahaan. Pihak manajemen diberikan tugas untuk menjalankan dana yang diberikan oleh principal, harus bertanggung jawab atas tugas yang diberikan kepadanya. Akan tetapi permasalahan yang sering terjadi adanya perbedaan sikap dan persepsi akan informasi yang akan diberikan ke principal.

Selain itu, perusahaan berkaitan dengan Earning Per Share (EPS). Earning Per Share menunjukkan bahwa perusahaan mengalami keuntungan maupun kerugian dan bisa dijadikan indikator terhadap tingkat nilai perusahaan. Jika perusahaan mengalami Earning Per Share negatif menyatakan bahwa perusahaan sedang mengalami kesulitan keuangan, dapat dilihat dari kinerja keuangan yang menyatakan laba bersih mengalami penurunan, laba operasi negatif (-), dan nilai buku ekuitas negatif (-). Apabila perusahaan memiliki Earning Per Share positif bearti membuktikan bahwa perusahaan mampu memberikan kesajahteraan yang tinggi dengan menghasilkan laba per saham yang tinggi, begitu juga sebaliknya. 
Menurut penelitian Pramudena(2017) menunjukkan bahwa managerial ownership dan institusional ownership tidak berpengaruh terhadap kemungkinan terjadinya financial distress. Penelitian Ahmad Khaliq dkk (2014) menunjukkan bahwa likuiditas (current ratio) dan leverage (debt ratio) mempunyai hubungan signifikan terhadap financial distress. Menurut Steven Sean \& Viriany (2016) menunjukkan bahwa leverage berpengaruh signifikan terhadap financial distress.

\section{KAJIAN TEORI}

Teori ini awalnya dikembangkan oleh Ross (1973), sedangkan penjelasan lebih detail dari teori keagenan pertama kali dinyatakan oleh Jensen and Mecking (1976) pada tulisan yang berjudul "Theory of the firm: Managerial behavior, agency costs, and ownership structure". Dari teori tersebut manajer suatu perusahaan sebagai "agen" dan pemegang saham "principal". Pemegang saham merupakan principal yang memberikan mandat pengambilan keputusan bisnis perusahaan kepada manajer yang merupakan perwakilan atau agen dari pemegang saham. Permasalahan yang muncul dari akibat sistem kepemilikan perusahaan ini adalah agen terkadang memberikan keputusan yang bertentangan sehingga menimbulkan persepsi yang berbeda akan penilaian perusahaan. Adanya penilaian dan kepentingan yang berbeda antara principal dan agen akan menimbulkan konflik keagenan.

Selain agency theory, penelitian ini juga menggunakan teori sinyal (signalling theory). teori ini diperkenalkan pertama kali oleh Spence (1973) dalam penelitiannya yang berjudul Job Market Signalling. Jadi Spence mengemukakan bahwa isyarat memberikan suatu sinyal yaitu pihak yang mempunyai informasi akan berusaha memberikan sejumlah informasi relevan yang dapat dimanfaatkan oleh pihak penerima. Pihak penerima kemudian akan menyesuaikan tindakannya sesuai dengan pengertiannya terhadap sinyal yang diterima tersebut.

Berikut kerangka pemikiran dalam penelitian ini : 
Gambar 1. Kerangka pemikiran

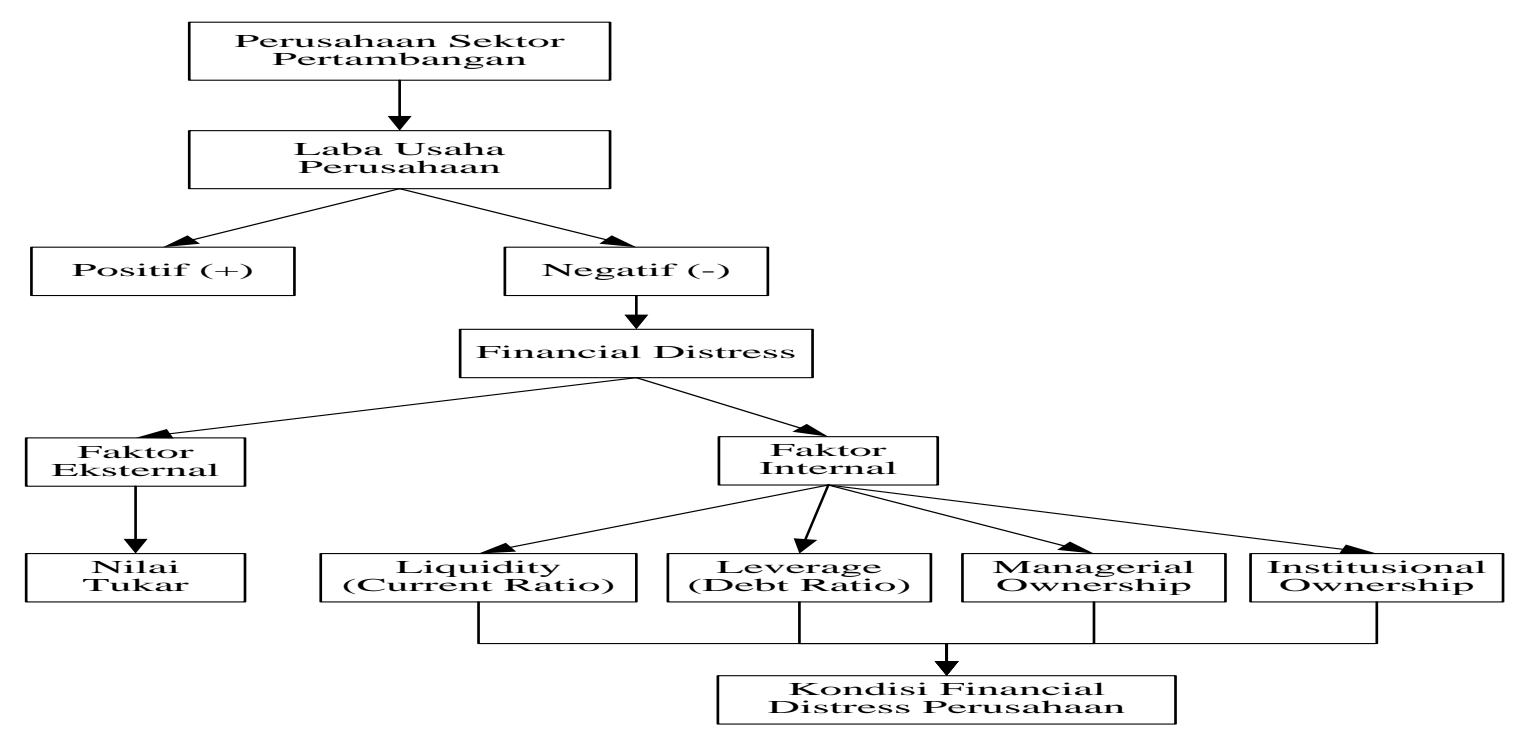

Pada lima tahun ini, sektor pertambangan mengalami penurunan dibandingkan sektor lain dikarenakan menurunnya permintaan akan komoditas pertambangan dan menurunya harga komoditas pertambangan dipasaran. Bahkan beberapa perusahaan yang dijadikan sampel mengalami penurunan laba usaha. Apabila kondisi ini terus menerus terjadi akan menyebabkan perusahaan mengalami financial distress (kesulitan keuangan).

Selain itu, faktor internal dalam penelitian ini yaitu managerial ownership berkaitan dengan persentase kepemilikan saham yang dimiliki manajemen dibandingkan dengan jumlah saham beredar yang dikeluarkan perusahaan. Institusional ownership berkaitan dengan persentase kepemilikan saham yang dimiliki institusi dibandingkan dengan jumlah saham beredar yang dikeluarkan perusahaan. Sedangkan liquidity berkaitan dengan kemampuan perusahaan untuk membayar kewajiban jangka pendek yang harus segera dilunasi. Dan leverage adalah kemampuan perusahaan dalam penggunaan hutang secara efisien untuk membiayai kegiatan investasi jangka pendek maupun jangka panjang yang dilakukan perusahaan.

Dari pembahasan diatas, maka terbentuklah kerangka pemikiran hipotesis seperti yang digambarkan pada gambar 1. financial distress merupakan salah satu faktor yang mempengaruhi keuangan suatu perusahaan, sehingga pentingnya tata kelola perusahaan maupun pengelolaan keuangan yang baik dan benar. Oleh sebab itu dapat dirumuskan hipotesis sebagai berikut : 
H1 : Managerial ownership merupakan prediktor financial distress.

$\mathrm{H} 2$ : Institusional Ownership merupakan prediktor financial distress.

H3 : Likuiditas merupakan prediktor terhadap financial distress.

$\mathrm{H} 4$ : Leverage merupakan prediktor terhadap financial distress.

\section{METODOLOGI}

Metode pengambilan sampel yang dilakukan didalam penelitian ini adalah metode sensus. Metode ini adalah cara pengumpulan data dimana seluruh elemen populasi diselidiki satu persatu. Oleh sebab itu, data yang terkumpul dalam penelitian ini adalah 39 perusahaan pertambangan. Dalam penelitian ini menggunakan desain penelitian deskriptif. Penelitian ini menggunakan metode kuantitatif, dimana dalam metode ini lebih menekankan penghitungan, pengukuran seperti menggunakan simbol angka. Sumber data ini yang dipakai dalam penelitian ini adalah data sekunder, dikarenakan sumber data yang diperoleh peneliti dari pihak yang terpercaya.

Operasionalisasi variabel yang dilakukan pada variabel dependen dalam penelitian ini adalah menggunakan Earning Per Share. Maka rumus dari EPS dalam financial distress adalah sebagai berikut :

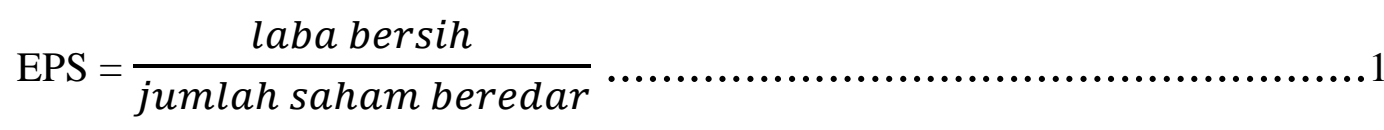

Sedangkan variabel independen dalam penelitian ini berkaitan dengan tata kelola perusahaan yaitu Pengukuran kepemilikan manajerial (Manegerial Ownership) sesuai dengan penelitian yang dilakukan oleh Rini dkk (2016), dirumuskan sebagai berikut :

$$
\mathrm{MO}=\frac{\begin{array}{c}
\text { jumlah kepemilikan } \\
\text { saham oleh manajemen }
\end{array}}{\text { jumlah saham yang beredar }} \times 100 \%
$$

Selain itu, Pengukuran kepemilikan institusional (Institusional Ownership) sesuai dengan penelitian yang dilakukan oleh Sri Marti Pramudena (2017), dirumuskan sebagai berikut :

$$
\mathrm{IO}=\frac{\begin{array}{c}
\text { jumlah kepemilikan } \\
\text { saham oleh } \text { institusi }
\end{array}}{\text { jumlah saham beredar }} \times 100 \%
$$


Berkaitan dengan variabel independen yang digunakan dalam rasio keuangan yaitu Likuditas diukur dengan menggunakan rasio current ratio sesuai dengan penelitian yang dilakukan Ahmad Khaliq dkk (2014), dirumuskan sebagai berikut :

$$
\text { LIQ }=\frac{\text { Aset lancar }}{\text { kewajiban lancar }}
$$

Leverage diukur dengan menggunakan debt ratio kontisten dengan penelitian yang dilakukan Ahmad Khaliq dkk (2014), dirumuskan sebagai berikut :

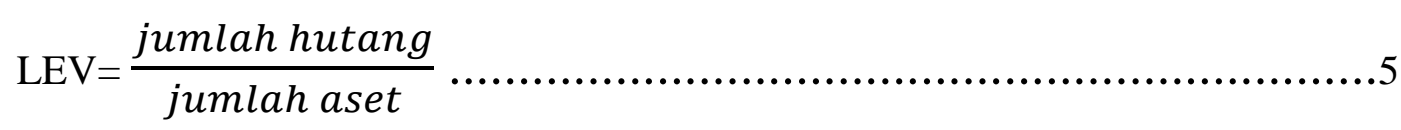

Dalam penelitian ini teknik pengolahan data yang digunakan adalah Uji Regresi Logistik (koefisien), uji Wald, Uji Hosmer and Lemeshow's Goodness of Fit, Koefisien Determinasi dengan menggunakan aplikasi Eviews.

\section{HASIL DAN PEMBAHASAN}

\section{Hasil Analisis Data}

Analisis Regresi Logistik. Dalam penelitian ini teknik analisis penelitian yang digunakan adalah model regresi logistik. Alasan menggunakan regresi logistik dikarenakan penggunaan variabel dummy dengan skala nominal pada variabel dependen yaitu financial distress (kesulitan keuangan). Berikut hasil pengujian regresi logistik yang disajikan dalam tabel 2 dengan menggunakan aplikasi eviews :

\begin{tabular}{|c|c|c|c|c|}
\hline \multicolumn{5}{|c|}{$\begin{array}{l}\text { Dependent Variable: FD } \\
\text { Method: ML - Binary Logit (Newton-Raphson / Marquardt steps) } \\
\text { Date: 07/12/19 Time: } 12: 36 \\
\text { Sample: } 20142018 \\
\text { Included observations: } 195 \\
\text { Convergence achieved after } 3 \text { iterations } \\
\text { Coefficient covariance computed using observed Hessian }\end{array}$} \\
\hline Variable & Coefficient & Std. Error & z-Statistic & Prob. \\
\hline $\begin{array}{l}\text { C } \\
\text { MO } \\
\text { IO } \\
\text { LIQ } \\
\text { LEV }\end{array}$ & $\begin{array}{r}-1.163099 \\
0.023550 \\
0.009041 \\
-0.003869 \\
0.682083\end{array}$ & $\begin{array}{l}0.768787 \\
0.013043 \\
0.006856 \\
0.001769 \\
0.704656\end{array}$ & $\begin{array}{r}-1.512901 \\
1.805585 \\
1.318727 \\
-2.186743 \\
0.967966\end{array}$ & $\begin{array}{l}0.1303 \\
0.0710 \\
0.1873 \\
0.0288 \\
0.3331\end{array}$ \\
\hline
\end{tabular}

Tabel 2. Hasil Uji Regresi Logistik

Sumber : diolah penulis

Tabel 2 menunjukkan bahwa hasil pengujian analisis regresi logistik dengan dilihat nilai koefisien. Nilai koefisien dalam regresi logistik berfungsi untuk 
menunjukkan arah. Berdasarkan hasil pengujian regresi logistik yang dilakukan pada tabel 4.1, maka dapat dirumuskan model persamaan regresi logistik sebagai berikut : Financial Distress $=\operatorname{Ln} \frac{p i}{1-p i}=-1.163099+0.023550 \mathrm{MO}+0.009041 \mathrm{IO}-0.003869$ LIQ

$$
+0.682083 \mathrm{LEV}
$$

Uji Wald. Berdasarkan hasil pengujian ini akan dilihat dari nilai probabilitas dari masingmasing variabel independen. Pengujian ini bertujuan untuk melihat hasil signifikansi antara variabel independen terhadap variabel dependen. Berikut ini terdapat masing-masing pengujian variabel:

Variabel managerial ownership, institusional ownership, dan leverage mempunyai nilai probabilitas sebesar $0,0710,0,1873$, dan 0,3331 yang lebih besar dari 0,05 . sehingga dapat disimpulkan bahwa Ho tidak ditolak, tidak terdapat pengaruh yang signifikan antara managerial ownership, institusional ownership, leverage terhadap terjadinya financial distress pada perusahaan pertambangan yang terdaftar di BEI dengan tingkat kepercayaan sebesar $95 \%$.

Sedangkan variabel liquidity mempunyai nilai probabilitas sebesar 0,0288 yang lebih kecil dari 0,05. sehingga dapat disimpulkan bahwa Ho ditolak, terdapat pengaruh yang signifikan antara likuiditas terhadap financial distress pada perusahaan pertambangan yang terdaftar di BEI dengan tingkat kepercayaan sebesar 95\%.

\section{Uji Hosmer dan Lemeshow's Goodness of Fit}

Tabel 3. Hasil Uji Hosmer dan Lemeshow's Goodness of fit

\begin{tabular}{|l|c|}
\hline Number of observations & 196 \\
\hline Number of groups & 10 \\
\hline Hosmer-Lemeshow's chi2 (8) & 0,5156 \\
\hline Prob > chi2 & 0,6396 \\
\hline
\end{tabular}

Sumber : diolah penulis

Berdasarkan dari tabel 3, hasil uji Hosmer and Lemeshow's Goodness of Fit menunjukkan bahwa hasil nilai chi square hitung sebesar 0,6396 atau 63,96\% yang berarti 
lebih besar daripada 0,05 atau 5\%, sehingga dapat diambil kesimpulan bahwa H0 tidak ditolak. Jadi dapat diambil kesimpulan bahwa model yang diuji cocok dengan data dengan tingkat keyakinan $95 \%$.

\section{Koefisien Determinasi}

Tabel 4. Hasil Uji Koefisien Determinasi

\begin{tabular}{|l|c|}
\hline Number of observations & 196 \\
\hline Pseudo R Square $\left(R^{2}\right)$ & 0,0611 \\
\hline
\end{tabular}

Sumber : diolah penulis

Dari tabel 4, nilai $\mathrm{R}^{2}$ sebesar 0,0611 $(6,11 \%)$. Hasil pengujian ini menunjukkan bahwa sebesar 6,11\% variabel dependen financial distress (kesulitan keuangan) dapat dijelaskan oleh variabel-variabel independen, antara lain managerial ownership, institusional ownership, liquidity, dan leverage. Sedangkan sisanya sebesar 93,89\% dapat dijelaskan oleh variabel-variabel lain di luar penelitian ini.

\section{DISKUSI}

Berdasarkan hasil pengujian yang dilakukan dalam penelitian ini managerial ownership, institusional ownership, leverage mempunyai pengaruh positif dan tidak signifikan terhadap financial distress. Hal ini disebabkan adanya asimetri informasi, kepemilikan yang terpusat dan pendanaan yang lebih banyak menggunakan hutang. Sedangkan likuiditas mempunyai pengaruh negatif dan signifikan terhadap financial distress. Artinya jika perusahaan mampu membiayai kewajiban jangka pendeknya dengan baik, maka potensi financial distress yang akan dialami perusahaan semakin kecil dan begitu sebaliknya.

\section{KESIMPULAN}

Berdasarkan penelitian ini, masih banyak kekurangan sehingga ada beberapa saran yang di berikan sebagai berikut : 
1. Bagi peneliti berukutnya, disarankan untuk meneliti variabel-variabel lain yang belum digunakan pada peneltian ini sehingga hasil yang didapatkan dapat lebh luas. Penelitan ini hanya menggunakan sektor pertambangan, diharapkan ada penelitian lainnya dengan variabel yang sama untuk meneliti sektor lainnya dengan variabel yang sama sehingga dapat diketahui variabel yang mana yang paling dominan di setiap sektor yang berbeda.

2. Diharapkan manajemen perusahaan khususnya pada perusahaan sektor pertambangan yang terdaftar di Bursa Efek Indonesia dalam periode 2014-2018 untuk memperhatikan managerial ownership, institusional ownership, liqudity dan leverage sehingga dapat mengurangi kemungkinan terjadinya financial distress. Untuk mengurangi kemungkinan terjadinya financial distress perusahaan secara signifikan, disarankan manajemen perusahaan lebih memperhatikan liquidity karena dalam liquidity memiliki pengaruh yang signifikan terhadap financial distress.

\section{DAFTAR PUSTAKA}

Ajija, Shochrul R et al. (2011). Cara Cerdas Menguasai Eviews. Jakarta: Salemba Empat. Cinantya, I. A., \& Merkusiwati, N. L. (2015). Pengaruh Corporate Governance, Financial Indicators, dan Ukuran Perusahaan Pada Financial Distress. E-Jurnal Akuntansi Universitas Udayana, 897-915.

Damayanti, L.H., Gede, A.Y., Ni, K.S. (2017). Analisis Pengaruh Kinerja Keuangan, Ukuran Komite Audit dan Kepemilikan Manajerial terhadap Financial Distress. Journal accountant, 1(7).

Elloumi, F., \& Gueyie, J.-P. (2001). Financial Distress and Corporate Governance : an Empirical Analysis. Corporate Governance : The International Journal of Business in Society, 1,1, 15-23.

Elkhal Khaled, (2019). Business Uncertainty and Financial Leverage: Should the Firm Double up on Risk. Managerial Finance, 4 (25), 536-544.

Hapsari, Evanny Indri.(2012). Kekuatan Rasio Keuangan dalam Memprediksi Kondisi Financial Distress Perusahaan Manufaktur yang terdaftar di BEI. Jurnal Dinamika Akuntansi, 2(3), 101-109.

Jensen, M. C., \& Meckling, W. H. (1976). Theory of The Firm : Managerial Behavior, Agency Costs and Ownership Structure. Journal of Financial Economics 3, 305-360.

Jiming, Li dan Du Weiwei. (2011). An Empirical Study on the Corporate Financial Distress Prediction Based on Logistic Model Evidence from China's Manufacturing Industry. International Journal of Digital Content Technology 5(6).

Khaliq, A., Altarturi, B. H., Thaker, H. M., Harun, M. Y., \& Nahar, N. (2014). Identifying Financial Distress Firms : A Case Study of Malaysia's Government Linked Companies (GLC). International Journal of Economics, Finance and Management, 3(3), 141-150. 
Pramudena, S. M. (2017). The Impact of Good Corporate Governance on Financial Distress in the Consumer Goods Sector. Journal of Finance and Banking Review, 2(4), 46-55.

Salehi Mahdi, Afsaneh Lothfi, Shayan Farhangdoust. (2017). The Effect of Financial Distress Costs On Ownership Structure and Debt Policy: An Application of Simultaneous Equations in Iran. Journal of Management Development, 10(36), 12161229.

Seoki, Lee., Yoon Koh, dan Chang Huh. (2010). Financial Distres U.S. Lodging Industry: Effects Of Leverage, Capital Intensity, And Internationalization. International CHRIE Conference-Refereed Track. Paper 3

Spence, Michael. (1973). Job Market Signaling. The Quarterly Journal of Economics, 3(87) 355-374.

Sean Steven \& Viriany. (2016). Pengaruh Rasio Keuangan terhadap Financial Distress. Jurnal Ekonomi, XXI (01), 43-60.

UNDANG-UNDANG REPUBLIK INDONESIA NOMOR 1 TAHUN 2014 TENTANG MINERBA 